PS
3174
W5833fl 


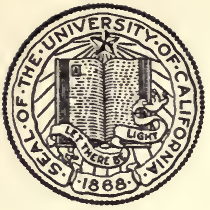

THE LIBRARY

OF

THE UNIVERSITY

OF CALIFORNIA

LOS ANGELES 
Le ex d dow and Itristares orrs. 

FLOWERS FROM ARCADIA. 




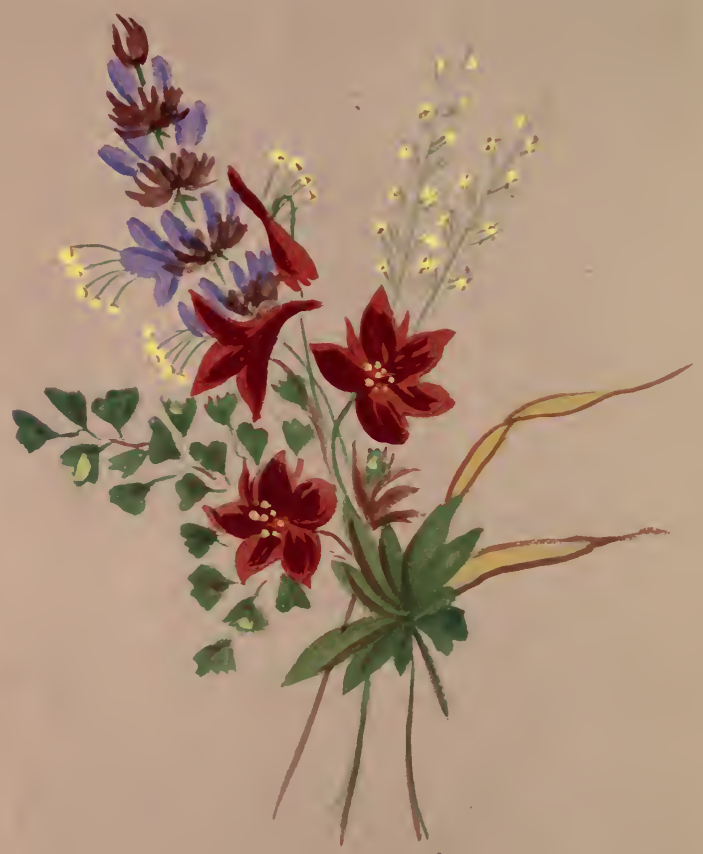




\section{FLOWERS FROM ARCADIA}

A Series of Rondeaux and Verses showing the various Flowers of Affection that Blossom by the Wayside of Life

ILLUSTRATED WITH STEEL ENGRAVINGS

AND EMBELLISHED WITH CALIFORNIA WILD FLOWERS

\section{$\mathfrak{A}$ Cbristmas Greeting}

BY

JAMES T. WHITE

Copyright, 1884

JAMES T. WHITE \& CO., Publishers

23 Dupont St., San Francisco 



\section{PS \\ 3174 \\ W5833 fl}

\section{DEDICATION.}

EAR friend, though seen by other eyes,
Your heart must read through all disguise, What tender meaning underlies

This Christmas Greeting:

For you these humble flowers grow;

To you their sweet-breathed greetings go,-

The message you already know

Once more repeating. 



\section{PRELUDE.}

$A$ BOOK of songs, a jar of wine,

A A loaf, and Thou, dear friend of mine,

Beside me in the Wilderness;-

Oh! then the Wilderness zoould be

Arcadia indeed to me,

So great would be my happiness.

Paraphrased from the Persian of Omar Khayyam.

TO Arcady hast thou ne'er been?

Then let me give the mystic key,-

The passwerd that shall take thee in

To Arcady.

LOVE.-Love that worketh charity;

That holdeth all mankind as kin;

That beareth human sympathy.

Love is the only door therein;

And Love, the "open sesame"

Whereby thou may'st an entrance win

To Arcady. 



\section{CONTENTS.}

Dedication.

Prelude.

I. Nemophila, . . . . . . . . Admiration

II. Columbine, . . . . . . . . Entanglement

III. Brodiæa, . . . . . . . . Devotion

IV. Platystemon, . . . . . . . . Confession

V. Ceanothus, . . . . . . . Absence

VI. Chlorogalum, . . . . . . . . Longing

VII. Tricostema, . . . . . . . . Entreaty

VIII. Scarlet Larkspur, . . . . . . . Betrothal

IX. Manzanita, . . . . . . . . Marriage

X. Fritillaria, . . . . . . . . Paternity

XI. Geyser Lily, . . . . . . . . Anniversary

XII. Mariposa Lily, . . . . . . . Solicitude

XIII. Thurberia, . . . . . . . Commemoration

XIV. California Ázalea, . . . . . . . Retrospection

XV. Eschscholtzia, . . . . . . . Twilight

XVI. Clematis, . . . . . . . . Trust

L'Envoi. 

FLOWERS FROM ARCADIA.

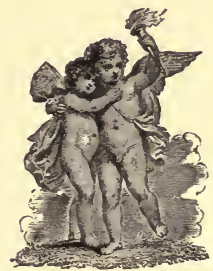





\title{
NEMOPHILA.
}

\author{
ADMIRATION.
}

Camöens wrote a sonnet to his sweetheart, Catrina, the refrain of which was,

"Szueetest eyes were cuer seen."

ROUNDEL.

"SIVEETEST eyes were ever seen."

$\checkmark$ Could the Poet e'er devise

Daintier praise, - than gave Catrine Sweetest eyes?

And which are the sweetest eyes?

Soft and melting, lustrous, keen, Merry,-or demure and wise?

Eyes that shine with light serene,

Mirrored from Love's happy skies,-

Like thine own, dear,-are, I ween, Sweetest eyes. 



\title{
COLUMBINE.
}

\author{
ENTANGLEMENT.
}

After Herrick.

BEE-KISSED Columbine,

Tell this sweet friend of mine

That she,

Like thee,

Hath ruby lip

Where I would sip,

Like wanton bee.

And too, like thee,

She bends her lily head

And smiles,--but ties

My heart with subtle thread

Drawn from her eyes.

She prisons me,-

But then, ah me!

Her dungeon takes from me

All wish for liberty:

Her sweet bond blesses me,

Her smile caresses me,

And in her gentle heart I lie

At rest,

Caressed

By Love's delicious lullaby. 



\section{$=\quad$ BRODIÆA.}

DEVOTION.

Rondeau.

IN days gone by these wild flowers fair

1 Were made sweet messengers to bear

My homage and fond thoughts to you,--

If peradventure they might woo

Your maiden fancy unaware.

To me these sweet-breathed blossoms are

Reminders still of that fond care

For you, which in my bosom grew

In days gone by.

Your dear familiar face they wear,

And in their beauty I compare

The old-time charm they bring anew:-

I wonder if they bring to you

The message they were wont to bear

In days gone by? 



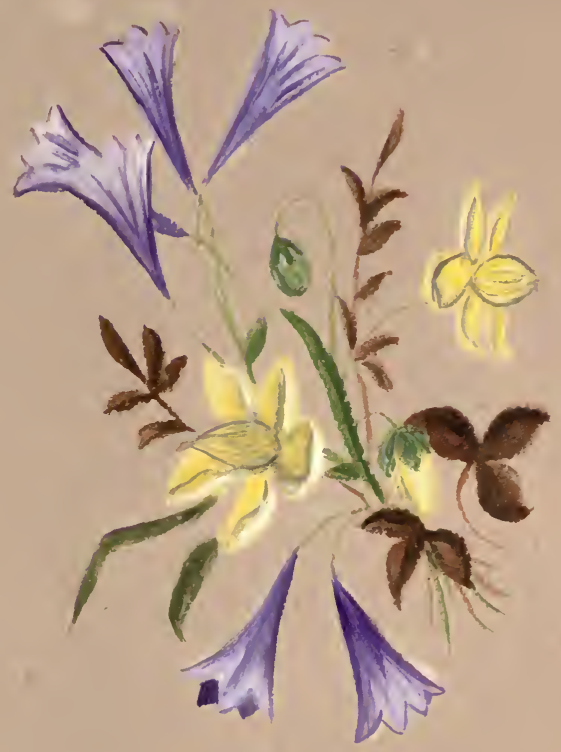

BRODIEA. 


\section{PLATYSTEMON.}

CONFESSION.

Can I teach thee, my beloved?

Can I teach thee?

Can I bless thee, my beloved?

Can I bless thee?

Alas! I can but love thee.

-Mrs. Browning.

$T \begin{gathered}\text { HOU hast taught me, my beloved; } \\ \text { Thou hast taught me: }\end{gathered}$

Taught me Life's profounder meaning;

Taught me honor, virtue,-weaning

Me from all ignoble things:

On Imagination's wings

Taught me how to soar, and find

Rarest pleasure in the mind :

Taught me Life's dull incompleteness

Without Love's renewing sweetness:

From the height of thy pure soul

Taught me passion to control;

And hast brought me

At thy gentle feet to learn

What thy clearer eyes discern.

Thou hast blessed me, my beloved,

Thou hast blessed me :

Blessed me with thy tender eyes,

Which look on me in such a wise

My faint soul grows strong again,

As the flowers after rain:

And they rest me,

While they more and more enchain.

Thou hast blessed me with thy words:

Sweeter than the song of birds,

They have soothed my weary brain,

Banished every care and pain

That distressed me, 


\section{-}


And a new strength put within me

To resist delights that win me

From the duty God commands.

Thou hast blessed me with thy hands,

Which have ever shared my toil,

Heeding neither ache nor soil,

And caressed me,

Making all my burdens lighter,

And the sky of hope still brighter.

Dear hands, - only made for smoothing

Restless pillows, and for soothing

Tired hearts, - would they were mine

To have and hold by right divine!

Dost thou love me, my beloved?

Dost thou love me?

Thou whom I have from afar

Watched and worshipped, like a star

That above me

Shines, and yet may never know

The blessing that its beams bestow?

Thou hast taught me, thou hast blessed me,

And with happiest thoughts possessed me,

But to love me

Is the crowning of all blessing;

Making me by thy confessing

Rich beyond all power to measure,-

Royal,- - crowned by thy sweet pleasure

Sovereign of a fair domain

I had never thought to gain.

Blessing, honor, rest, thou art,

And with undivided heart,

Dear, I love thee,-

Love thee more than words can tell:-

And I would that my caressing

Could bring thee so rich a blessing,

And forever more compel

Love's peace in thy heart to dwell. 


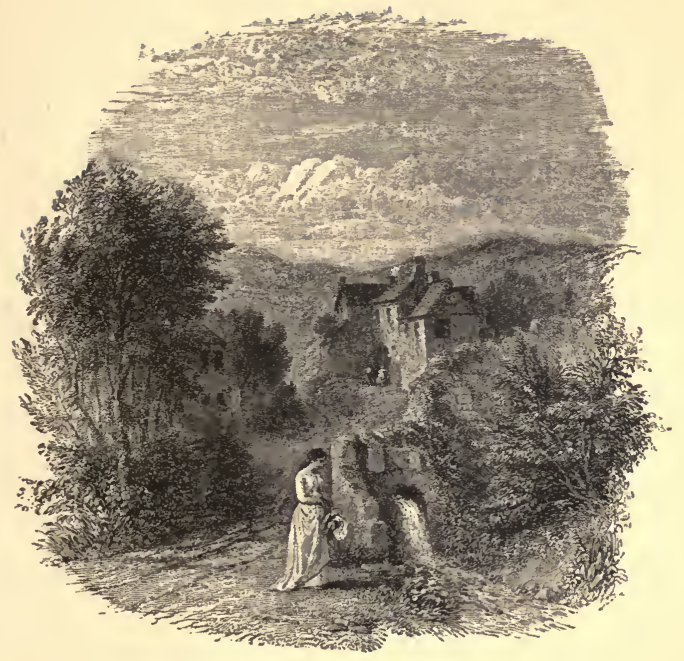


ABSENCE.

THE day is night when thou art gone; the night Is long, and silence, like a roaring sea

By angry tempest driven, thunders on

My utter loneliness and solitude.

$\mathrm{O}$ friend beloved, how can I part from thee!

How can I say farewell to those bright eyes,-

Those eyes which bless me with their tender light!

How can I say farewell to those soft hands,-

Those hands which hold me in their light caress!

How can I say farewell to those sweet lips,Those lips which teach me Love's divinest law! How can I say farewell to that dear heart,That heart which is to me my Heaven, my all! No, no, dear love, I cannot part from thee: My heart on angel wings will follow thee, And find thee, wheresoe'er thou art; will hold Thee still in sweet embrace, and whisper Love's Unwearied story to thy listening ear.

My thoughts in sweet companionship will still Thy gentle footsteps lead where sunniest skies Their azure keep undimmed, and genial climes Perpetual fragrance shed. My thoughts, with Love's Transforming wand, will touch the wild flowers in Thy path, and bid them yield a sweeter breath And wear for thee a brighter face and smile. They will sweet odors bring of home and friends And dear remembered hours, if haply they May tempt a restless, wandering thought, and turn Remembrance back to homelier scenes-and me.

Sweet heart, my thoughts thy guardian angels be, And bring thee safe to home, and love, and me! 



\title{
CHLOROGALUM.
}

\author{
LONGING. \\ "And then I know some thought from you \\ Has fown across the night and found me. \\ And though I love, and though I trust, \\ And yet will love and trust forever, \\ Ah! dear, I long and ycarn for just \\ One glance, one touch to still the ferer."
}

MY OWN DEAR LOVE,

\section{Your tuneful lay}

Has found me weary, sad and lonely; The promise of my strife has fled, And left me disappointment only. Could you have known my weariness, Or known how great my heart's depression, Your pitying thoughts could not have sent More healing balm than this confession.

Yes, dear, my restless thoughts have flown Across the night, to you returning

Like carrier birds at last set free Instinctively their home discerning. They must have told you, dear, how much I want you, need you every hour; That life without you is unblest,The perfume gone from every flower. 
-

- 
I long and yearn for you as well, To hold you in Love's fond caresses:

One glance, one touch will never fill The need my waiting heart confesses.

I want you in my daily life,-

My dear companion, fond and tender:

And you shall be my rest,-my joy, And I, your helpmeet and defender.

Whene'er I read your matchless lines, Of fond regret and hopeful waiting, Their tender longing lifts my heart To you in happy contemplating. Their music round me weaves a tie, Nor distance, age, nor time can sever; And, dear, to strengthen this sweet bond, Shall be through life my one endeavor. 
$-$ 


\section{TRICOSTEMA.}

ENTREATY.

RONDEAU.

$A$ BIDE with me, $O$ gentle guest!

A Thy presence brings to me sweet rest; Thy hands bring soothing to my brow;

Thy words such sympathy avow, Thy going leaves me all unblest.

Still fairer shall thy bower be dressed; Anticipated each request;

One song thy life shall be, if thou Abide with me.

I would not longer have thee guest;

I cannot hold thee uncaressed

So near my heart: Sweet love, be thou

My bride; Love's tend'rest name allow, And ever in his happy rest

Abide with me. 
1 


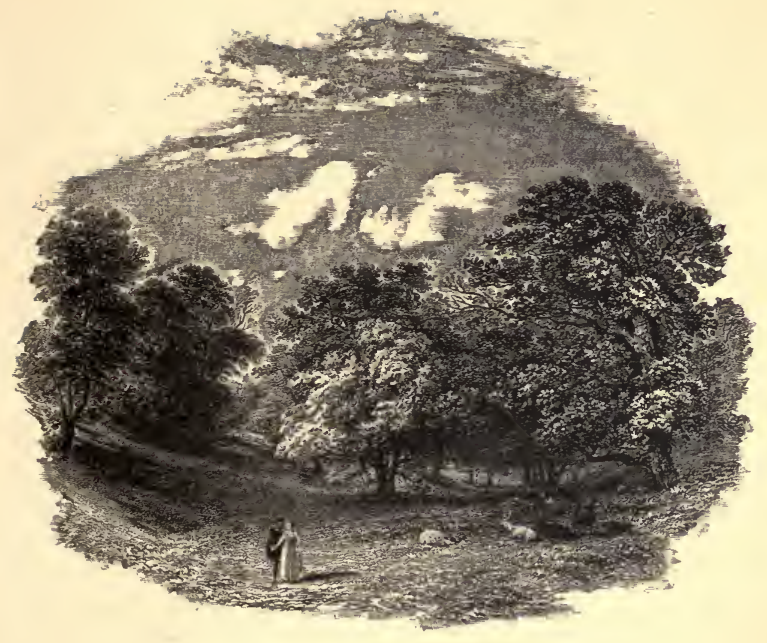


$\div$ 
SCARLET LARKSPUR.

BETROTHAL.

ROUNDEL

"I WILL thy lot and.portion share;

I Will love and honor thee, and fill

The measure of thy need, whate'er $I$ will."

This tender flower cherish, till

In Heaven it blooms more bright and fair,For love in Heaven will blossom still.

And Love's fair flower hath made thee heir To a new life beyond death's chill;Eternity hath heard this, dear, "I will." 


\section{MANZANITA.}

MARRIAGE.

RoNdeav.

HEART, beloved! I dedicate, The powers and aims of man's estateThe dearest hopes of life to thee; Thy happiness my care shall be, On every wish my love shall wait.

I sought thee not for wealth nor state; Though countless graces on thee wait, 'Twas thy sweet, loving self made thee.

$\mathrm{O}$ heart, beloved.

If frowning fortune be our fate, More tender and affectionate

My sympathizing love shall be;

No ills that Heaven may decree

Our knitted souls can separate,

$\mathrm{O}$ heart, beloved: 


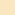




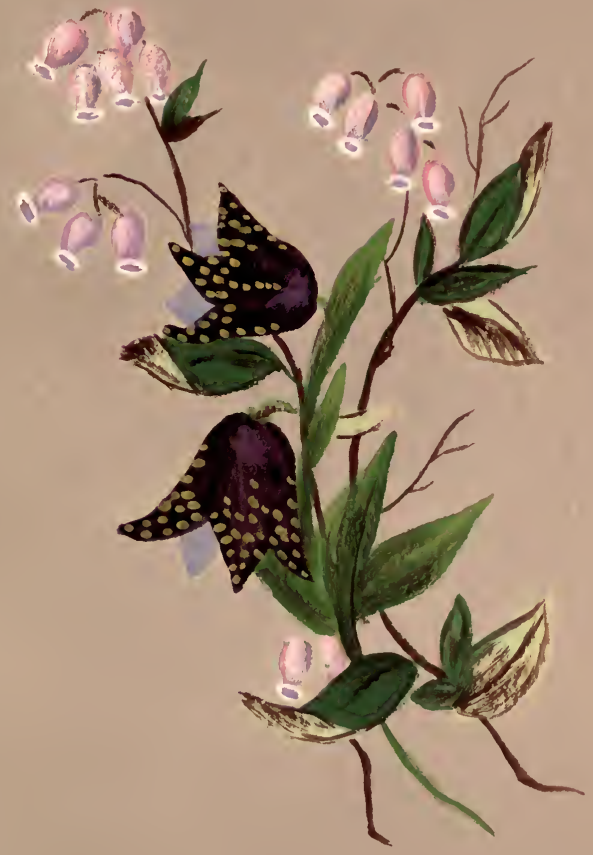

MANZANITA.

FRITILLARIA. 


\section{FRITILLARIA.}

PATERNITY.

ROU NDEL.

I'M four years old;- - and by the way

That must be why my papa told

Me not to cry, because to-day

I'm four years old.

I'll try and not again be told;

And when I may not have my way

I'll strive the starting tears to hold.

But when I hurt myself if they

Do come, and will not be controlled, I'll stop, and to myself I'll say,

"I'm four years old." 



\section{GEYSER LILY.}

ANNIVERSARY.

Ronueau.

THE bells were told to ring in glee The day when first thou cam'st to be Our home's delight; and in my heart, By Love's supreme, mysterious art, These bells have rung unceasingly.

And on this day there comes to me Anew the tender memory

Of that sweet joy, which but in part The bells were told.

Dear child, in whose sweet eyes I see The Heaven that waits above for me, How far from me would Heaven depart; How comfortless would be my heart, If through some darkened day for thee The bells were tolled! 



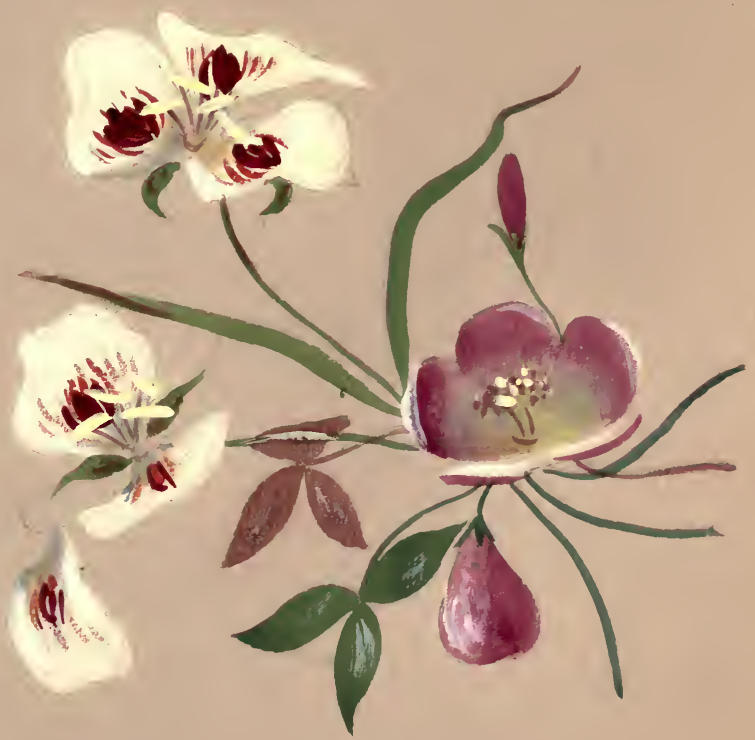




\section{$y$}

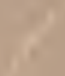

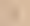

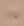
s.

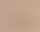




\title{
MARIPOSA LILY.
}

\author{
SOLICITUDE.
}

ROUNDEL.

L IKE one of these, Art hath not made Attire that can our eyes so please; E'en Solomon was not arrayed

Like one of these.

Consider how they grow in ease And leisure, dancing in the glade Like butterflies upon the breeze.

Then be not thou with burdens weighed;

If $\mathrm{He}$ a flower's need o'ersees

Thou too shalt on His care be laid

Like one of these.

Mariposa-Spanish for Butterfly. 
e 


\section{THURBERIA.}

COMMEMORATION.

THESE wedding bells for fifteen years Have rung alternate joys and knells, Till now our deepened love endears These wedding bells.

These fifteen years, dear wife, have brought

Much more of happiness than tears, While Love has many lessons taught These fifteen years.

Love taught us, dear, that hearts are torn

By words and looks, as millstones tear; That burdens shared, are easiest borne, Love taught us, dear.

As years go by, with ruddier glow Shall Love adorn our sunset sky; And closer still our hearts shall grow, As years go by. 
.

.

1 


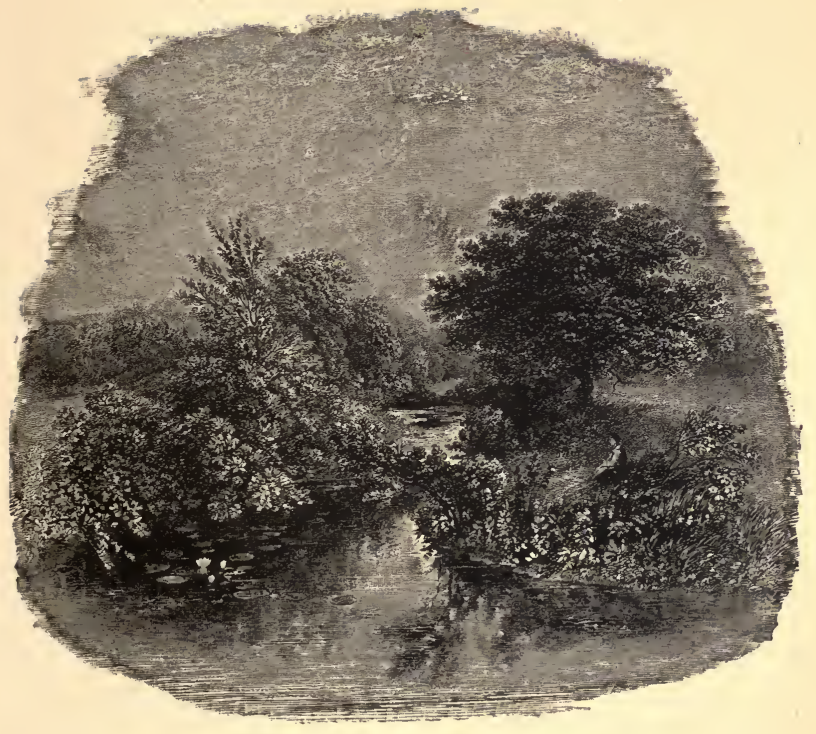


RETROSPECTION.

THE Christmas Bells from hill and tower

To-night their benedictions shower;

And on the waves of their sweet chimes,

Fond thoughts of home and olden times

Set sail through memory's Golden Gate:

Deep laden with love's precious freight, They speed their homeward course to-night Across the sea with Ariel flight.

O you, who wait returning sails,

Whose eyes hope long-deferred o'erveils

With lowering clouds, take heart again!

For lo! unseen through mist and rain

Of tears, a thousand white-winged keels,

Afloat on billowy Christmas peals,

Seek haven in your hearts to-night,

Home guided by love's beacon light.

Dear friends, though sundered far and wide;

Though varied quests our thoughts divide,

May these rich argosies of love

My tender, faithful memory prove;

May they to-night new love awake,

And in this festive season make

Your hearts forget the old farewells,

In greetings brought by Christmas Bells. 



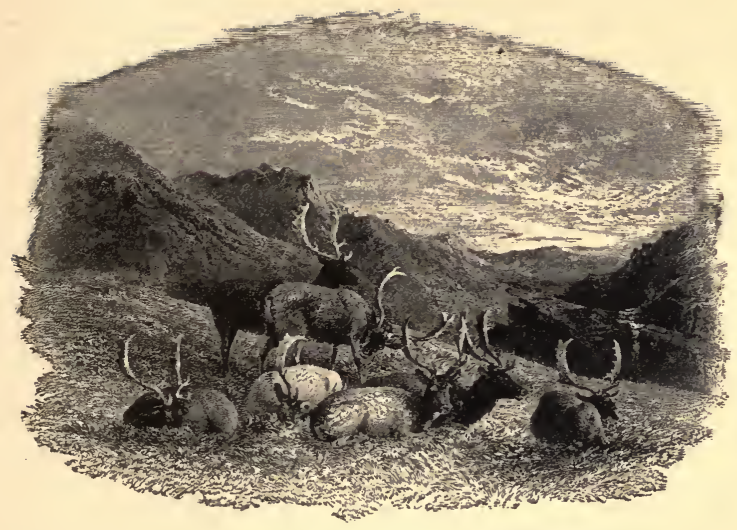




\section{ESCHSCHOLTZIA.}

TWILIGHT.

$A$ s children, when the day is done A And twilight deepens, one by one Around the evening fireside come With happy faces; Brightening the home with quiet cheer, And drawing every heart more near In perfected affection's dear

And fond embraces:

So may sweet memories come to you; And whisp'ring the old love anew May thoughts of those long lost to view Around you cluster:

May their fond greetings so delight That you forget the gathering night, While earth's horizon grows more bright With heavenly luster.

Without a thought of vain regret, Then may these latter days be set In Joy's completed coronet,

Heaven's richest dower:

May they with blessings be replete; And be, in Love's reunion sweet, A season when loved memories meet,Life's twilight hour. 


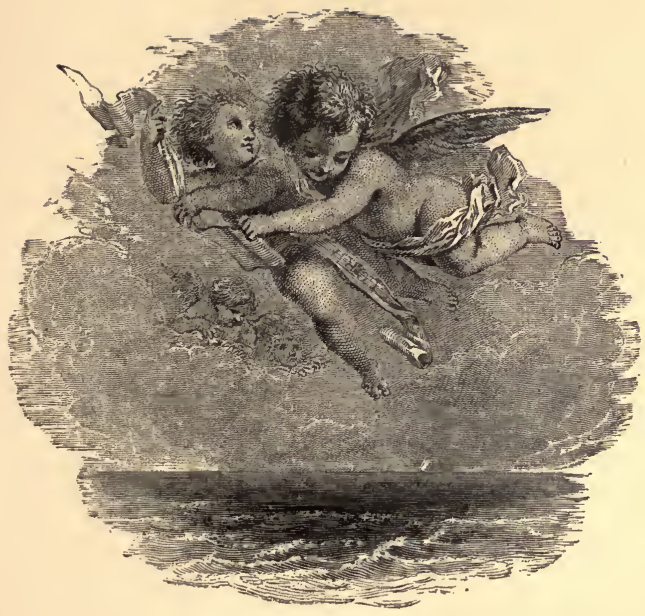




\section{CLEMATIS.}

TRUST.

RoNDEAU.

IF hearts are dust, hearts' loves remain, And somewhere, far above the plane

Of earthly thought, beyond the sea

That bounds this life, they will meet thee And hold thee face to face again.

And when is done Life's restless reign,

If I hereafter but regain

Heart's love, why should I troubled be,

If hearts are dust?

By Love's indissoluble chain,

I know the grave does not detain

Heart's love. The very faith in me

Is pledge of an eternity,

Where I shall find heart's love again,

If hearts are dust. 



\section{L'ENVOI.}

THAT I might share with thee, dear friend, the sweet Enjoyment Memory brings, I've sought to lay On these fair pages little bits of tint And color-here and there a study, worked, Sometimes in smiles, sometimes in tears, - if they Perchance might hold thy wandering thoughts awhile, And lead thee back to Arcady - and me. 




\section{UNIVERSITY OF CALIFORNIA LIBRARY \\ Los Angeles}

This book is DUE on the last date stamped below.

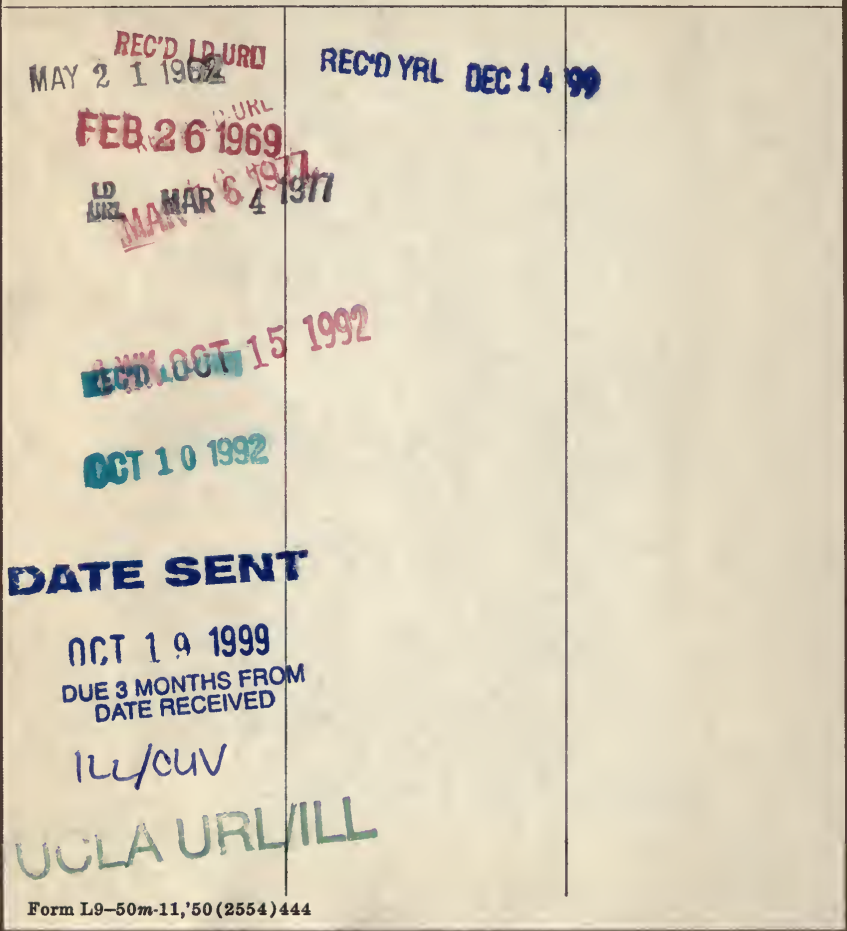


